\title{
Silent Somatotroph Adenoma: A Morphologic, Immunohistochemical and Electron Microscopic Study: A Case Report
}

\author{
Aydin Sav ${ }^{\mathrm{a}, \mathrm{f}}$, Luis V Syro ${ }^{\mathrm{b}}$, Bernd W Scheithauer ${ }^{\mathrm{c}}$, Fabio Rotondo ${ }^{\mathrm{d}}$, \\ Carlos A Builes ${ }^{\mathrm{e}}$, Eva Horvath ${ }^{\mathrm{d}}$, Kalman Kovacs ${ }^{\mathrm{d}}$
}

\begin{abstract}
Pituitary adenoma, removed surgically from a 22 old young man with normal serum growth hormone level, and no evidence of acromegaly by histology, immunohistochemistry and electron microscopy was studied. Ultrastructurally the tumor cells were shown to correspond to sparsely granulated somatotrophs and immunohistochemistry showed no, moderate, or little growth hormone. Clinically silent somatotroph adenomas so far are unresolved entities; although electron microscopy shows that they are consisted of sparsely granulated somatotrophs they do not secrete substantial amounts to raise growth hormone and IGF-1 blood levels. Further work is required to clarify the mechanisms accounting for the clinical and biochemical silence of these tumors.
\end{abstract}

Keywords: Electron microscopy; Histology; Immunohistochemistry; Pituitary adenoma; Endocrine silence

Manuscript accepted for publication November 17, 2011

${ }^{\text {a } D e p a r t m e n t ~ o f ~ P a t h o l o g y, ~ A c r b a d e m ~ U n i v e r s i t y, ~ S c h o o l ~ o f ~ M e d i c i n e, ~}$ Maltepe, Istanbul, Turkey

${ }^{b}$ Department of Neurosurgery, Clinica Medellin and Hospital Pablo Tobon Uribe, Medellin, Colombia

${ }^{\mathrm{c}}$ Department of Anatomic Pathology, Mayo Clinic, Rochester, MN, USA

${ }^{\mathrm{d}}$ Department of Laboratory Medicine, St Michael's Hospital, University of Toronto, Toronto, Ontario, M5B 1W8, Canada

${ }^{\mathrm{e}}$ Division of Endocrinology, Clinica Medellin and Hospital Pablo Tobon Uribe, Medellin, Colombia

${ }^{\mathrm{f}}$ Corresponding author: Aydin Sav, Department of Pathology, Acibadem University, School of Medicine, Gulsuyu Mahallesi, Fevzi Cakmak

Cd, Divanyolu Sok, 1, Maltepe, Istanbul, Turkey.

Email:sav.aydin@yahoo.com

doi:10.4021/jmc416w

\section{Introduction}

Somatotroph adenomas (GH producing adenomas, somatotrophinomas) are typically secreting $\mathrm{GH}$ excessively and cause the clinical syndrome of acromegaly or in the prepubertal age: gigantism. This recognition not only identifies a sellar mass as a GH producing adenoma but expands the therapeutic alternatives. Sporadic reports in the relevant literature also describe "silent somatotroph adenomas" referring to adenomas that can be recognized as somatotroph adenomas' by positive immunohistochemical staining for $\mathrm{GH}$, but are not associated with clinical evidence of GH excess. Some of these adenomas are entirely silent, in that not associated with either clinical manifestations of GH excess or elevated serum concentrations of GH ad IGF1[1-5]. Others are "clinically silent"; in terms of elevated GH and IGF1 serum concentrations but not accompanied by clinical manifestations of GH excess [2, 6-14]. The objective of this study was the data extracted in terms of histology, immunohistochemistry and electron microscopy of a silent somatotroph adenoma. Therefore, we reviewed clinical records and had the detailed analysis of the relevant morphologic information including immunohistochemistry and electron microscopy.

\section{Case Report}

A 22-year-old man presented in January 2011. 6 months before he started to have poor concentration, headache and recently he noticed visual acuity diminution. At physical examination there was right homonymous hemianopsia. Blood hormone levels were as follows: Growth hormone $0.5 \mathrm{ng} /$ $\mathrm{ml}$ (normal < 5.0); insulin-like growth factor (IGF-1) 274.9 $\mathrm{ng} / \mathrm{ml}(48$ - 255); prolactin $6.5 \mathrm{ng} / \mathrm{ml}(0$ - 15); luteinizing hormone (LH) $2.5 \mathrm{mUI} / \mathrm{ml}$ (2 - 12); follicle stimulating hormone (FSH) $1.7 \mathrm{mUI} / \mathrm{ml}(1-8)$; thyroid stimulating hormone (TSH) $3.0 \mathrm{mUI} / \mathrm{ml}(0.5-6.0)$, free thyroxin (T4) 1.0 $\mathrm{ng} / \mathrm{dl}(0.8-1.8)$, and cortisol $14.9 \mathrm{mcg} / \mathrm{ml}(5-25)$. MRI disclosed a large tumor $(6 \mathrm{~cm} \times 6 \mathrm{~cm})$ which occupied the sella, with invasion to the sphenoid sinus, left cavernous sinus and extension to the temporal lobe and suprasellar area, 


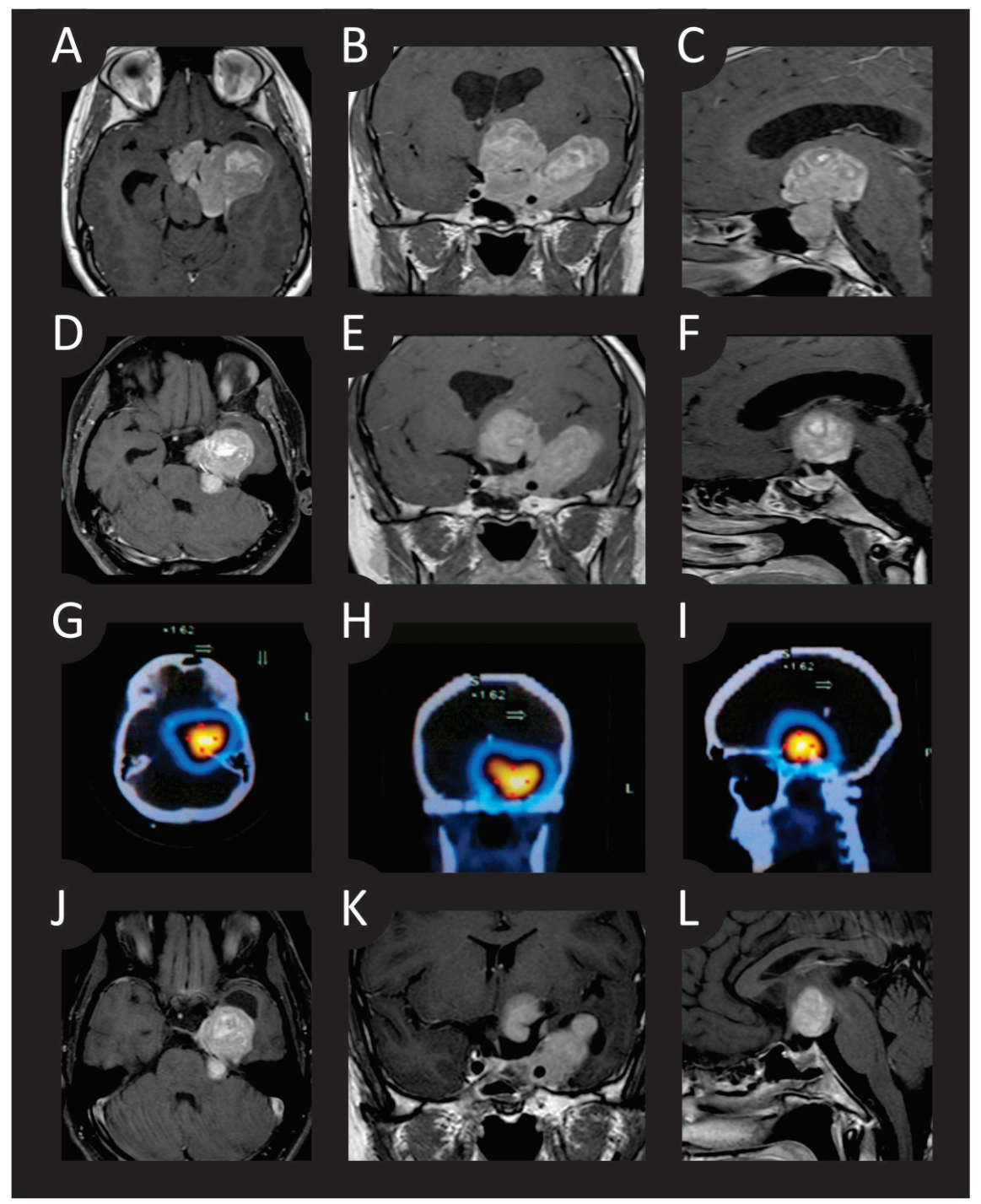

Figure 1. Preoperative T1- weighed MRI with contrast enhancement (A: axial; B: coronal; C: sagittal.). Post operative T1-weighed MRI with contrast enhancement showing resection of the intrasellar portion of the tumor (D: axial; E: coronal; F: sagittal.). Octreoscan images shows lesion (G: axial; H: coronal; I: sagittal.). T1-weighted MRI with contrast enhancement scans 3 months after surgery and Octreotide treatment shows $20 \%$ shrinkage of tumor size. (J: axial; K: coronal; L: sagittal)

approximately $6 \mathrm{~cm} \times 4 \mathrm{~cm}($ Fig. $1 \mathrm{~A}, \mathrm{~B}, \mathrm{C})$. There was hydrocephalus due to obstruction of the Foramen of Monro. He underwent a biventricular peritoneal shunt on February 7, 2011 and transsphenoidal surgery on February 22, 2011. Resection of the tumor in the sella was performed (Fig. 1 D, E, F). At the immediate post operative period he presented with a seizure. CT disclosed obstructive hydrocephalus and subarachnoid hemorrhage. Cerebral angiography did not show vascular lesion and a VP shunt revision was done. He presented with right hemiparesis and aphasia probably due to vasospasm that improved during the following days. At $10^{\text {th }}$ postoperative day he complained of pain in the right leg. Right deep venous thrombosis was documented and an inferior cava filter was placed without complications. Post- operative MRI disclosed adequate resection of the tumor in the sella. After the pathology report of silent somatotroph adenoma an Octreoscan was performed that was positive (Fig. 1G, H, I). He started Octreotide $30 \mathrm{mg} /$ month on April 2011. The last Octreoscan showed performed 3 months later showed $20 \%$ shrinkage in tumor size (Fig. 1J, K, L).

\section{Materials and methods}

All tissue samples were fixed in $10 \%$ buffered formalin, routinely processed, paraffin embedded cut to $5 \mu \mathrm{m}$, and stained with hematoxylin and eosin (H\&E) and PAS. For immunohistochemistry the streptavidin-biotin-peroxidase complex method was used and antisera were directed against GH, 


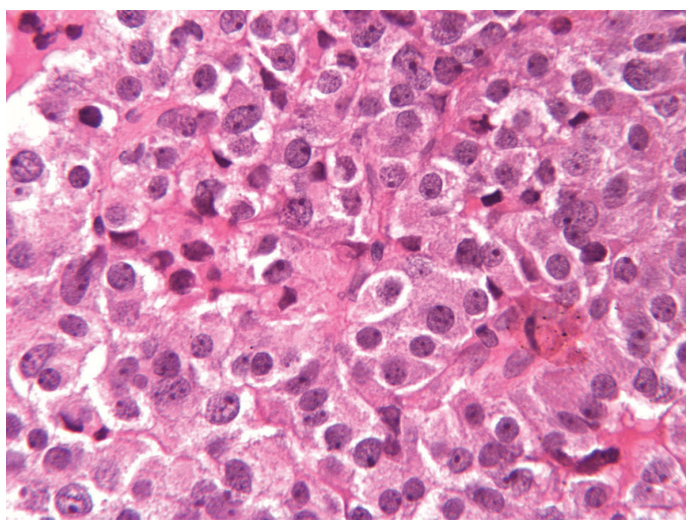

Figure 2. No major cellular and nuclear pleomorphism was seen and mitotic figures were not obvious (Original magnification $\times 400$ ).

PRL, ACTH, TSH, LH, FSH, as well as the alpha-SU of glycoprotein hormones. Methods of immunostaining, antibody sources and dilations have previously been described [15].

Electron microscopy had also been performed for diagnostic purposes. For electron microscopy, tissues were fixed in $2.5 \%$ glutaraldehyde, postfixed in $1 \%$ osmium tetroxide, dehydrated in graded series of ethanol, processed through propylene oxide, and embedded in an Epon-araldite mixture. Ultrathin sections were stained with lead citrate ad uranyl acetate and studied with a Hitachi 7650 electron microscope.

\section{Results}

\section{Histologic and immunohistochemical findings}

By light microscopy, a chromophobic PAS negative pituitary adenoma was identified. The tumor was diffusely arranged. No major cellular and nuclear pleomorphism was seen and mitotic figures were not obvious (Fig. 2). Immunostainings demonstrated immunopositivity for GH in several unevenly

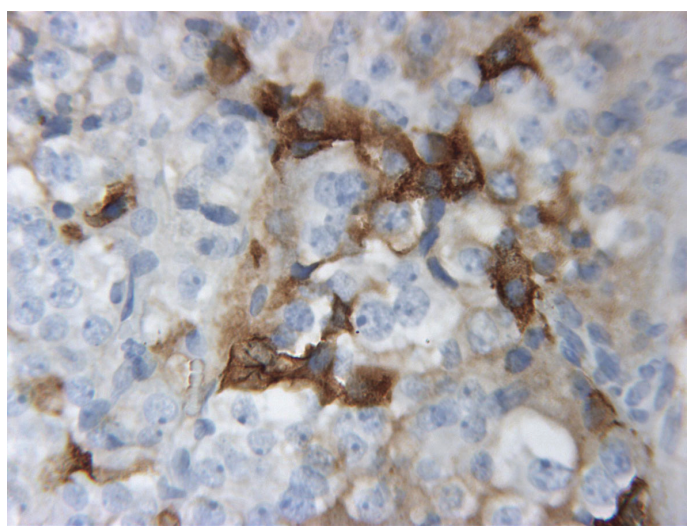

Figure 3. Immuno-positivity for $\mathrm{GH}$ in several unevenly distributed adenoma cells (original magnification $\times 400$ ).

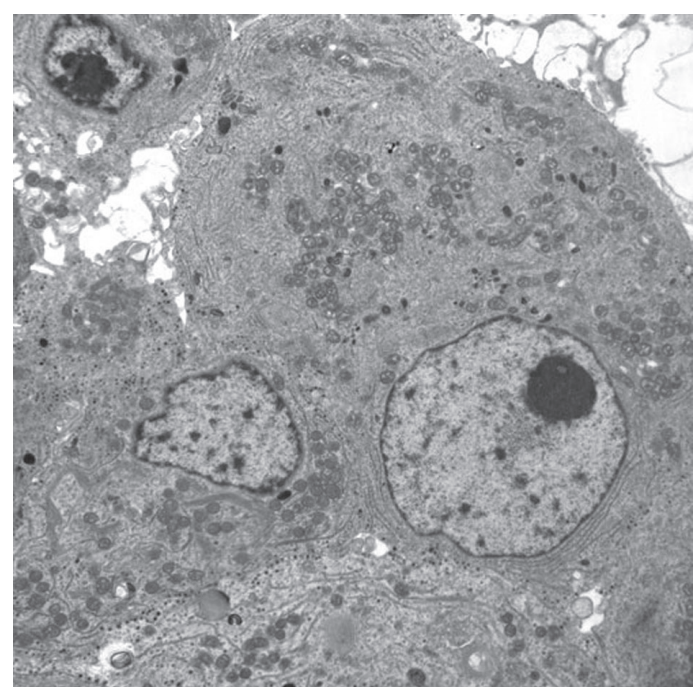

Figure 4. Typical tumor cells having large nucleus, prominent dense nucleolus, but very little heterochromatin $(\times 7000)$.

distributed adenoma cells (Fig. 3) and for PRL in occasional adenoma cells. Immunostaining were negative for ACTH, TSH, FSH, LH and alpha subunit. The Ki-67 nuclear labeling index using the MIB1 antibodies was estimated at $1 \%$. Many tumor cell nuclei were immunopositive for MGMT, a DNA repair enzyme.

\section{Ultrastructural findings}

Electron microscopy documented a variably cellular adenoma comprising closely apposed or partially connected small to midsized rounded cells. The roughly spherical nuclei had large dense nucleolus and very little fine granular

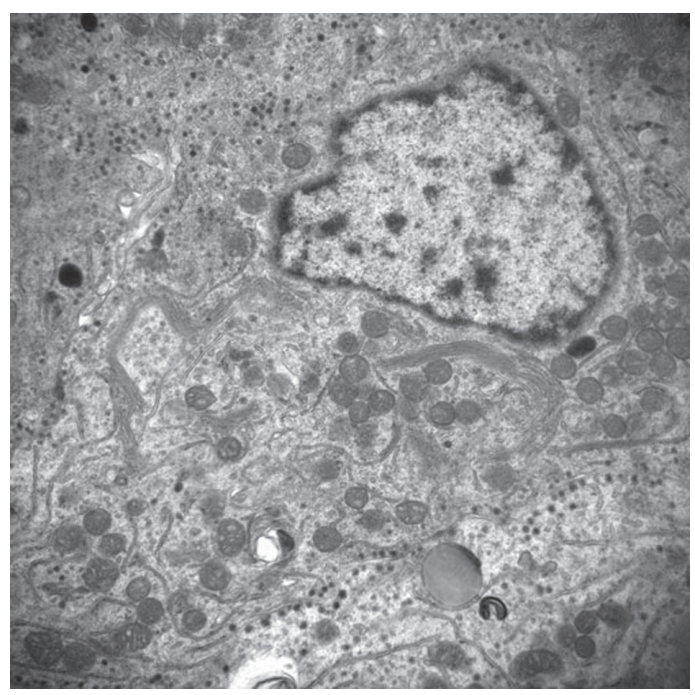

Figure 5. Electron micrograph depicting tumor cells containing collapsed inactive Golgi membrane, but no fibrous body was noted in Golgi area (× 15000). 
heterochromatin. The cytoplasm contained well developed RER, less than abundant free polyribosomes, numerous small spherical mitochondria, and in many cells, a sizeable fibrous body consisting of a mixture of SER membranes and cytokeratin filaments (Fig. 4). An obvious abnormality was the scarcity of the lean-looking inactive Golgi membranes usually noticeable only in cells without fibrous body (Fig. 5 ). The peripherally located sparse minute secretory granules measure no more than 71 to $126 \mathrm{~nm}$ (mean: $87 \mathrm{~nm}$ ).

\section{Discussion}

Somatotroph adenomas in which there is laboratory and immunohistochemical evidence of GH excess in the absence of clinical manifestations of acromegaly were first reported in 1985 [6]. It was observed that two women who had no clinical features of acromegaly but did have non-suppressible serum GH concentrations had pituitary adenoma that, after excision, showed immunohistochemical staining for GH. The term "clinically silent somatotroph adenoma" was first used 2 years later in describing three women with nonsuppressible serum GH concentrations with no acromegaly and positive GH staining of the excised adenoma tissue [7]. The largest previous series of clinically silent somatotroph adenomas described a total of 17 patients who had silent somatroph adenomas of which four were clinically silent [2]. These four patients had no clinical manifestations of acromegaly but did have elevated basal serum GH concentrations that did not suppress after administration of glucose.

The explanation for the lack of clinical and laboratory manifestations of some somatotroph adenomas compared with the obvious manifestations in others, even though exhibit elevated GH and/or IGF-1 concentrations, is not clear [16]. One of the possible explanations is a lesser duration of excessive GH secretion, but some reports describe these patients in whom excessive $\mathrm{GH}$ secretion has been properly documented for many years [11, 18]. The other explanation might be the ineffective secretion of GH or secretion of biologically inactive GH. These possibilities may explain by finding understandable elevation of serum IGF-1 in the patients with somatotrophinomas. On the other hand, in one series, due to $30 \%$ of patients with clinically silent adenomas had serum IGF-1 concentrations more than twice the upper limit of normal, the mean IGF-1 concentrations were higher in those patients categorized as classic and subtle than in those classified as clinically silent [16].

So far, some genetic alterations has been documented which causing an increase in transcription, elevated mRNA levels, and an increased synthesis of the gene product [17]. Moreover, human growth hormone genes were found to be hypomethylated in a somatotroph adenoma in contrast to nonadenomatous pituitary gland, suggesting that hypomethylation may explain the increased gene expression resulting in increased growth hormone excess found in some patients [17]. Another possibility is that the tumors produced mostly an abnormal growth hormone that lacked immunoreactivity and biologic activity. A variety of growth hormones with restricted action has been reported [18-20]. This data was not supported by in vitro studies. The adenoma cells may have secreted radioimmunoassay-able growth hormone in culture medium. The levels of growth hormone release initially were low in comparison with the endocrinologically active somatotroph adenomas. After several days, growth hormone release increased 10-fold, suggesting that growth hormone secretion may have been suppressed initially. After a week of culture, adenoma cells responded with increased growth hormone after GRH stimulation in vitro. It may be that the growth hormone mRNA translated in vivo to growth hormone synthesis in quantities necessary to significantly elevate serum growth hormone and cause acromegaly [21]. Therefore, one or multiple steps of the formation or posttranslational processing of the gene might have been defective; these abnormalities may explain the clinical and biochemical silence associated with silent somatotroph adenomas.

In apparently silent somatotroph adenomas serum $\mathrm{GH}$ was within normal range, serum IGF-1 was elevated, GH positive cells were present and the patient was slightly acromegalic [22]. In our case, unevenly distributed GH and local PRL reacting cells were demonstrated, unaccompanied by clinical manifestations of acromegaly, but only a mild IGF1 elevation (274.9 ng/ml (48 - 225)) was present. Clinical data indicate that acromegaly develops slightly more often in males of middle age, whereas silent somatotroph adenomas are more common in females. The clinical significance of clinically nonfunctioning somatotroph adenomas is that in a certain percentage of patients, no other identifiable sellar mass is identified as a somatotroph adenoma unless just measurement of serum IGF-1 concentration.

Somatostatin receptors (SSTR) are widely distributed in various neuroendocrine cells; there are five subtypes of SSTR [23-27]. Somatostatin analogs have been shown to directly inhibit growth hormone secretion and tumorigenesis in GH-secreting pituitary tumors through SSTR-2 and/or SSTR-5 [23, 25, 26, 28]. In some reports somatostatin has an anti-proliferative effect in pancreatic cells via activation of tyrosine phosphatase through SSTR1 [26, 29, 30]. Additionally, it has an inhibitory effect on secretion of $\alpha$-subunit and chromogranin from human non-functioning tumors [31]. On the other hand, its effect on cell viability of human non-functioning pituitary adenomas is unclear [32]. Following his Octreoscan which proved to be positive, our case received Octreotide for his medical treatment. However, the effectiveness of somatostatin treatment for silent somatroph adenoma is controversial. Therefore, both SSTR profile and drug efficacy definitely needs further clarification.

In summary, more work is needed to resolve the molecular occurrences responsible for the inconsistency between 
the diverse morphologic criteria and endocrine activity of silent somatotroph adenomas.

\section{References}

1. Kovacs K, Lloyd R, Horvath E, Asa SL, Stefaneanu L, Killinger DW, Smyth HS. Silent somatotroph adenomas of the human pituitary. A morphologic study of three cases including immunocytochemistry, electron microscopy, in vitro examination, and in situ hybridization. Am J Pathol. 1989;134(2):345-353.

2. Trouillas J, Sassolas G, Loras B, Velkeniers B, Raccurt M, Chotard L, Berthezene F, et al. Somatotropic adenomas without acromegaly. Pathol Res Pract. 1991;187(8):943-949.

3. Naritaka H, Kameya T, Sato Y, Furuhata S, Otani M, Kawase T. Morphological characterization and subtyping of silent somatotroph adenomas. Pituitary. 1999;1(34):233-241.

4. Abe T, Taniyama M, Xu B, Ozawa H, Kawamura N, Shimazu M, Sasaki K, et al. Silent mixed corticotroph and somatotroph macroadenomas presenting with pituitary apoplexy. Acta Neuropathol. 2001;102(5):435-440.

5. Mohammed S, Syro L, Abad V, Salehi F, Horvath E, Scheithauer BW, Kovacs K, et al. Silent somatotroph adenoma of the pituitary in an adolescent. Can J Neurol Sci. 2009;36(1):123-125.

6. Tourniaire J, Trouillas J, Chalendar D, Bonneton-Emptoz A, Goutelle A, Girod C. Somatotropic adenoma manifested by galactorrhea without acromegaly. J Clin Endocrinol Metab. 1985;61(3):451-453.

7. Klibanski A, Zervas NT, Kovacs K, Ridgway EC. Clinically silent hypersecretion of growth hormone in patients with pituitary tumors. J Neurosurg. 1987;66(6):806-811.

8. Pestell R, Herington A, Best J, Boolell M, McKelvie P, Arnott R, Alford F. Growth hormone excess and galactorrhoea without acromegalic features. Case reports. $\mathrm{Br}$ J Obstet Gynaecol. 1991;98(1):92-97.

9. Yamada S, Sano T, Stefaneanu L, Kovacs K, Aiba T, Sawano S, Shishiba Y. Endocrine and morphological study of a clinically silent somatotroph adenoma of the human pituitary. J Clin Endocrinol Metab. 1993;76(2):352-356.

10. Matsuno A, Ogino Y, Katayama H, Osamura RY, Nagashima $\mathrm{T}$. Identification of a silent pituitary somatotropic adenoma based on a paradoxic response of growth hormone on a thyrotropin-releasing hormone or gonadotropin-releasing hormone provocation test. Am J Obstet Gynecol. 2001;184(3):286-288.

11. Sakharova AA, Dimaraki EV, Chandler WF, Barkan AL. Clinically silent somatotropinomas may be biochemically active. J Clin Endocrinol Metab. 2005;90(4):21172121.
12. Sen O, Ertorer ME, Aydin MV, Erdogan B, Altinors N, Zorludemir S, Guvener N. Silent pituitary macroadenoma co-secreting growth hormone and thyroid stimulating hormone. J Clin Neurosci. 2005;12(3):318-320.

13. Sidhaye A, Burger P, Rigamonti D, Salvatori R. Giant somatotrophinoma without acromegalic features: more "quiet" than "silent": case report. Neurosurgery. 2005;56(5):E1154; discussion E1154.

14. Kalavalapalli S, Reid H, Kane J, Buckler H, Trainer P, Heald AH. Silent growth hormone secreting pituitary adenomas: IGF-1 is not sufficient to exclude growth hormone excess. Ann Clin Biochem. 2007;44(Pt 1):89-93.

15. Thapar K, Kovacs K, Scheithauer BW, Stefaneanu L, Horvath E, Pernicone PJ, Murray D, et al. Proliferative activity and invasiveness among pituitary adenomas and carcinomas: an analysis using the MIB-1 antibody. Neurosurgery. 1996;38(1):99-106; discussion 106-107.

16. Wade AN, Baccon J, Grady MS, Judy KD, O'Rourke DM, Snyder PJ. Clinically silent somatotroph adenomas are common. Eur J Endocrinol. 2011;165(1):39-44.

17. U HS, Kelley P, Lee WH. Abnormalities of the human growth hormone gene and protooncogenes in some human pituitary adenomas. Mol Endocrinol. 1988;2(1):8589.

18. Baumann G, MacCart JG, Amburn K. The molecular nature of circulating growth hormone in normal and acromegalic man: evidence for a principal and minor monomeric forms. J Clin Endocrinol Metab. 1983;56(5):946-952.

19. Markoff E, Lee DW, Culler FL, Jones KL, Lewis UJ. Release of the 22,000- and the 20,000-dalton variants of growth hormone in vivo and in vitro by human anterior pituitary cells. J Clin Endocrinol Metab. 1986;62(4):664669.

20. Lewis UJ, Singh RNP, Lewis LJ, Abadi N. detection of the multiple forms of human growth hormone. Acromegaly: A century of Scientific and Clinical Progress. 1987;27-34.

21. Asa SL, Kovacs K, Horvath E, Singer W. Somatotroph adenomas of the human pituitary : structure-function analysis in vivo and in vitro (abstr) Endocrinology. 1987;1250 (suppl) 252.

22. Pagesy P, Li JY, Rentier-Delrue F, Delalande O, Le Bouc Y, Kujas M, Joubert D, et al. Growth hormone and somatostatin gene expression in pituitary adenomas with active acromegaly and minimal plasma growth hormone elevation. Acta Endocrinol (Copenh). 1990;122(6):745752.

23. Lamberts SW, Oosterom R, Neufeld M, del Pozo E. The somatostatin analog SMS 201-995 induces long-acting inhibition of growth hormone secretion without rebound hypersecretion in acromegalic patients. J Clin Endocrinol Metab. 1985;60(6):1161-1165.

24. Orth DN. Cushing's syndrome. N Engl J Med. 
1995;332(12):791-803.

25. Colao A, Ferone D, Marzullo P, Cappabianca P, Cirillo $\mathrm{S}$, Boerlin V, Lancranjan I, et al. Long-term effects of depot long-acting somatostatin analog octreotide on hormone levels and tumor mass in acromegaly. J Clin Endocrinol Metab. 2001;86(6):2779-2786.

26. Buscail L, Delesque N, Esteve JP, Saint-Laurent N, Prats $\mathrm{H}$, Clerc P, Robberecht P, et al. Stimulation of tyrosine phosphatase and inhibition of cell proliferation by somatostatin analogues: mediation by human somatostatin receptor subtypes SSTR1 and SSTR2. Proc Natl Acad Sci U S A. 1994;91(6):2315-2319.

27. Tateno T, Izumiyama H, Doi M, Yoshimoto T, Shichiri M, Inoshita N, Oyama K, et al. Differential gene expression in ACTH -secreting and non-functioning pituitary tumors. Eur J Endocrinol. 2007;157(6):717-724.

28. Oshino S, Saitoh Y, Kasayama S, Arita N, Ohnishi T, Kohara $\mathrm{H}$, Izumoto $\mathrm{S}$, et al. Short-term preoperative octreotide treatment of GH-secreting pituitary adenoma: predictors of tumor shrinkage. Endocr J. 2006;53(1):125-132.

29. Bevan JS, Atkin SL, Atkinson AB, Bouloux PM, Hanna F, Harris PE, James RA, et al. Primary medical thera- py for acromegaly: an open, prospective, multicenter study of the effects of subcutaneous and intramuscular slow-release octreotide on growth hormone, insulinlike growth factor-I, and tumor size. J Clin Endocrinol Metab. 2002;87(10):4554-4563.

30. Liebow C, Reilly C, Serrano M, Schally AV. Somatostatin analogues inhibit growth of pancreatic cancer by stimulating tyrosine phosphatase. Proc Natl Acad Sci U S A. 1989;86(6):2003-2007.

31. Zatelli MC, Piccin D, Bottoni A, Ambrosio MR, Margutti A, Padovani R, Scanarini M, et al. Evidence for differential effects of selective somatostatin receptor subtype agonists on alpha-subunit and chromogranin a secretion and on cell viability in human nonfunctioning pituitary adenomas in vitro. J Clin Endocrinol Metab. 2004;89(10):5181-5188.

32. Gruszka A, Kunert-Radek J, Radek A, Pisarek H, Taylor J, Dong JZ, Culler MD, et al. The effect of selective sst1, sst2, sst5 somatostatin receptors agonists, a somatostatin/dopamine (SST/DA) chimera and bromocriptine on the "clinically non-functioning" pituitary adenomas in vitro. Life Sci. 2006;78(7):689-693. 